\title{
Cancer, Viral
}

National Cancer Institute

\section{Source}

National Cancer Institute. Cancer, Viral. NCI Thesaurus. Code C18675.

Virus as an agent in the cause of a cancer. 